\title{
The effect of nanoemulsified methionine and cysteine on the in vitro expression of casein in bovine mammary epithelial cells
}

\author{
Tae-Il Kim ${ }^{1, a}$, Tae-Gyun Kim², , Dong-Hyun Lim', Sang-Bum Kim', Seong-Min Park', Hyun-Joo Lim', \\ Hyun-Jong Kim', Kwang-Seok Ki ${ }^{1}$, Eung-Gi Kwon ${ }^{3}$, Young-Jun Kim², , and Vijayakumar Mayakrishnan ${ }^{1, *}$
}

\author{
* Corresponding Authors: \\ Young-Jun Kim \\ Tel: +82-44-860-1040, Fax: +82-44-860-1048, \\ E-mail: yk46@korea.ac.kr \\ Vijayakumar Mayakrishnan \\ Tel: +82-41-580-3401, Fax: +82-41-580-3419 \\ E-mail: marulbiochem@rediffmail.com \\ 'Dairy Science Division, National Institute of Animal \\ Science, Rural Development Administration, Cheonan \\ 31000, Korea \\ ${ }^{2}$ Department of Food and Biotechnology, Korea \\ University, Sejong 30019, Korea \\ ${ }^{3}$ Hanwoo Research Institute, National Institute of \\ Animal Science, Rural Development Administration, \\ Pyeongchang 25340, Korea \\ a These authors contributed equally to this work. \\ ORCID \\ Young-Jun Kim \\ https://orcid.org/0000-0003-1447-7857 \\ Vijayakumar Mayakrishnan \\ https://orcid.org/0000-0002-6437-1463
}

Submitted Mar 15, 2018; Revised Apr 8, 2018; Accepted Jul 9, 2018
Objective: Dairy cattle nutrient requirement systems acknowledge amino acid (AAs) requirements in aggregate as metabolizable protein (MP) and assume fixed efficiencies of MP used for milk protein. Regulation of mammary protein synthesis may be associated with AA input and milk protein output. The aim of this study was to evaluate the effect of nanoemulsified methionine and cysteine on the in-vitro expression of milk protein (casein) in bovine mammary epithelial cells (MAC-T cells).

Methods: Methionine and cysteine were nonionized using Lipoid S 75 by high-speed homogenizer. The nanoemulsified AA particle size and polydispersity index were determined by dynamic light scattering correlation spectroscopy using a high-performance particle sizer instrument. 3-(4,5-Dimethylthiazol-2-yl)-2,5-diphenyltetrazolium bromide assay was performed to determine the cytotoxicity effect of AAs with and without nanoionization at various concentrations (100 to $500 \mu \mathrm{g} / \mathrm{mL}$ ) in mammary epithelial cells. MAC-T cells were subjected to $100 \%$ of free AA and nanoemulsified AA concentration in Dulbecco's modified Eagle medium/nutrient mixture F-12 (DMEM/F12) for the analysis of milk protein (casein) expression by the quantitative reverse transcription polymerase chain reaction method.

Results: The AA-treated cells showed that cell viability tended to decrease (80\%) in proportion to the concentration before nanogenesis, but cell viability increased as much as $90 \%$ after nanogenesis. The analysis of the expression of genetic markers related to milk protein indicated that; $\alpha_{\mathrm{s} 2}$-casein increased 2 -fold, $\kappa$-casein increased 5-fold, and the amount of unchanged $\beta$-casein expression was nearly doubled in the nanoemulsified methionine-treated group when compared with the free-nanoemulsified methionine-supplemented group. On the contrary, the non-emulsified cysteine-administered group showed higher expression of genetic markers related to milk protein $\alpha_{\mathrm{s} 2}$-casein, $\kappa$-casein, and $\beta$-casein, but all the genetic markers related to milk protein decreased significantly after nanoemulsification.

Conclusion: Detailed knowledge of factors, such nanogenesis of methionine, associated with increasing cysteine and decreasing production of genetic markers related to milk protein (casein) will help guide future recommendations to producers for maximizing milk yield with a high level of milk protein casein.

Keywords: Casein; Amino Acids; Methionine; Cysteine; Mammary Epithelial Cells

\section{INTRODUCTION}

Dairy cattle nutrient requirement systems consider amino acids (AA) requirements to be essential in aggregate as metabolizable protein (MP) and assume fixed efficiencies of MP used for milk protein. They are used to determine the amount of absorbed AAs or nitrogen (N) required to support a preferred level of milk production with milk protein [1]. The AA composition affects the synthesis of milk protein. The exact amount of limited AA in dairy cow diets is unknown, and cows are overfed to meet the equilibrium of MP needed. This leads to 
AA waste and poor $\mathrm{N}$ efficiency [2]. In the previous literature, approximately $25 \%$ of dietary $\mathrm{N}$ is captured in milk, and the remaining approximately $75 \%$ is captured in urine and feces of dairy cows [3]. Therefore, feeding cows with a low protein concentration of essential and non-essential AA supplements may maintain and improve the total $\mathrm{N}$ efficiency [4-6]. In lactating dairy cows, AAs play a significant role in mammary protein synthesis. The previous literature on AA metabolism has mainly focused on balanced diets, which are necessary to maintain and enhance milk protein synthesis in lactating cows [7]. In mammals, AAs not only work as precursors for the synthesis of milk protein but also as signaling molecules for the regulation of protein synthesis and lactation [8]. For example, Moshel et al [9] reported that leucine supplementation increases the $\beta$-lactoglobulin synthesis in mouse and bovine mammary epithelial cells. Furthermore, isoleucine, methionine and threonine affect milk protein (casein) synthesis when removed from the culture medium of bovine mammary epithelial cells. So, a sufficient supply of AAs can increase the MP of milk protein and milk yield. Numerous studies have shown that AAs stimulate the synthesis of milk protein, which is mediated by mammalian target of rapamycin (mTOR) [10]. Histidine was the first AA found for the synthesis of milk protein [4]. Previous literature also demonstrated that introduction of histidine enhanced milk protein secretion [11]. A study by Appuhamy et al [6] showed that the addition of histidine to the cells activated the mTOR pathway and promoted milk protein synthesis, which upregulated phosphorylation of the downstream protein. Similarly, histidine was one of the transcriptional factors of the mTORC1 pathway, and it was negatively regulated by phosphorylated S6 kinase 1 and decreased the $\beta$-casein synthesis rate [12]. The consequences of essential AAs on milk protein synthesis and the mTOR signaling pathway have been extensively studied [13].

Nanoemulsification is a promising technology that has been used in various fields, including the pharmaceutical and food industries, with several potential applications. It is defined as a process by which substances of core materials are surrounded by a wall material to obtain capsules [14]. Liposomes are nanosized vesicles consisting of a membrane-like phospholipid bilayer surrounding an aqueous medium. Liposomes have been widely used in the pharmaceutical, food, and cosmetic industries, and have been successfully employed for the encapsulation of a wide range of synthetic drugs and bioactive molecules $[15,16]$. The application of liposomes onto bioactive compounds at the nanoscale range protects them from chemical degradation by the surrounding dispersion medium. Encapsulation implements the controlled release of bioactive molecules at the right place and time and it also increases the shelf life of bioactive molecules. Liposomes can be prepared as Lipoid S 75 (phosphatidylcholine [PC] $>75 \%$ ) from soybean lecithin. Amphiphilic lipoid S 75 is composed of a hydrophilic head domain and hydrophobic tail domain. This can come from the liposome in the aqueous media having a structure of a hydrophilic surface and a hydrophobic inner layer. It would be an ideal core material to prepare carriers for a nutrient which has the biological activity itself [17]. To the best of our knowledge, there is no scientific data on the effect of nanoemulsified AAs in casein expression. Therefore, the purpose of this experiment was to determine the effect of liposome-coated methionine and cysteine on the in vitro expression of milk protein casein in bovine mammary epithelial cells.

\section{MATERIALS AND METHODS}

\section{Cell culture and chemicals}

The mammary epithelial (MAC-T) cell line (ATCC: CRL-10274) was procured from the American Type Culture Collection (Rockville, MD, USA). Dulbecco's modified Eagle medium (DMEM), fetal bovine serum (FBS), penicillin, streptomycin, gentamicin, and hydrocortisone were purchased from GibcoBRL (Gaithersburg, MD, USA). The kit for mRNA isolation and reverse transcription polymerase chain reaction (RTPCR) kit were procured from Invitrogen (Carlsbad, CA, USA). 3-(4,5-Dimethylthiazol-2-yl)-2,5-diphenyltetrazolium bromide (MTT) was obtained from Amresco (Solon, OH, USA). Insulin was purchased from Sigma Aldrich (St. Louis, MO, USA). All other chemicals and solvents were of analytical grade. Lipoid S 75, Lipoid S 100, Lecinol S 10, Hydrogenated soybean phosphatidylcholine (HSPC) 50, Lipoid S 75-3, and Lipoid S 100-3 were purchased from Pharmachem (Seoul, Korea).

\section{Production of nanoemulsion for amino acids delivery}

The AAs were encapsulated in lecithin (Lipoid S 75)-based nanoemulsions, produced by high-pressure homogenization (HPH), as described by a previous study. Briefly, $10 \mathrm{wt}$. \% of AAs were diluted with $10 \mathrm{wt}$. $\%$ of ethanol, and then the mixture was added to $5 \mathrm{wt}$. $\%$ of lecithin, $75 \mathrm{wt}$. $\%$ of water and stirred by blender (develop pre-emulsion) until completely emulsified by high-speed homogenization using an Ultra Turrax T25 blender (IKA Labortechnik, Germany) for $4 \mathrm{~min}$ at 24,000 rpm, to achieve a primary emulsion. After that, cooled pre-emulsion was passed through a high-pressure homogenizer (MN400BF, Micronox, Seongnam, Korea) 3 times at $1,000 \mathrm{psi}$, resulting in nanoemulsion. The collected nanoemulsified AAs (methionine and cysteine) were used for further analysis.

\section{Particle size and polydispersity analysis}

The particle size distribution and polydispersity (zeta potential) of the nanoemulsified methionine and cysteine were analyzed by dynamic light scattering correlation spectroscopy using a high-performance particle sizer instrument (Malvern Instruments, Malvern, UK). The droplet size distribution was 
characterized regarding the mean droplet size (Z-diameter) and width of the distribution (polydispersity index, PDI) at a scattering angle of $190^{\circ}$ at $25^{\circ} \mathrm{C}$. Briefly, by measuring the backscattered light of $100 \mu \mathrm{L}$ samples diluted in $1 \mathrm{~mL}$ of distilled water put into a polystyrene latex cell and measured at a scattering angle of $90^{\circ}$, dispersant refractive index of 1.33 , and material refractive index of 1.59 at $25^{\circ}$.

\section{Cytotoxicity of nanoemulsions}

MTT was used in cytotoxicity analysis. Briefly, cells were seeded in a 96-well plate at a density of $0.5 \times 10^{4}$ cells/well. After a 24-h interval, cells were treated with different concentrations (100 to $500 \mu \mathrm{g} / \mathrm{mL}$ ) of nanoemulsified AAs (methionine and cysteine). After $48 \mathrm{~h}$ of incubation at $37^{\circ} \mathrm{C}$ with $5 \% \mathrm{CO}_{2}$, cells were treated with $10 \mu \mathrm{L}$ of MTT solution and incubated for $4 \mathrm{~h}$. The optical density of each well was measured at a wavelength of $540 \mathrm{~nm}$ using a Spectra count enzyme-linked immunosorbent assay plate reader (Packard Instrument Co., Downers Grove, IL, USA). The cytotoxicity of the blank nanoencapsulated AAs was expressed as the percentage of cell viability, calculated from the ratio between the numbers of living cells treated with the nano-encapsulated AAs and that of the untreated cells. Based on the cytotoxicity data, the concentration of encapsulated AAs $(18 \mu \mathrm{g} / \mathrm{mL})$ was chosen for the present study.

\section{Cell culture and treatment}

Bovine mammary epithelial cells were cultured in a 12-well plate at a density of $1.5 \times 10^{4}$ cells/well in DMEM supplemented with $10 \%$ of FBS, $100 \mu \mathrm{g} / \mathrm{mL}$ of penicillin and streptomycin, $5 \mu \mathrm{g} / \mathrm{mL}$ of insulin, $50 \mu \mathrm{g} / \mathrm{mL}$ of gentamicin, and $1 \mu \mathrm{g} / \mathrm{mL}$ hydrocortisone in a humidified atmosphere, including 5\% $\mathrm{CO}_{2}$ at $37^{\circ} \mathrm{C}$. After cells reached approximately $90 \%$ to $100 \%$ confluency, they were treated with nanoemulsified AAs (methionine and cysteine) at a concentration of $18 \mu \mathrm{g} / \mathrm{mL}$ for 24 $\mathrm{h}$. The experiment performed in triplicate.

\section{Milk protein gene expression quantification by} quantitative reverse transcription polymerase chain reaction

At the end of the experiment, cellular mRNA was extracted from MAC-T cells by a RNeasy lipid tissue kit (Qiagen, Valencia, CA, USA) according to the manufacturer's protocol.
Extracted RNA was quantified with UVS-99 microvolume UV/Vis spectrometer-ACT gene. cDNA synthesis was performed with $500 \mathrm{ng}$ of cellular RNA using oligo (dT) primers and reverse transcriptase provided by the Superscript III firststrand synthesis system for RT-PCR (Invitrogen, USA). The level of casein-related gene mRNA expression was assessed by SYBR Green-based real-time PCR on an ABI 7500 PCR system (Applied Biosystem, Foster City, CA, USA). The target gene expression levels were normalized against housekeeping gene glyceraldehyde 3-phosphate dehydrogenase. Primers used for quantitative RT-PCR are listed in Table 1.

\section{Statistical analysis}

All the experiments were conducted in triplicate. Data were statistically analyzed, and comparison was performed using a statistical package (SPSS-16.0) (SPSS, Inc., Chicago, IL, USA). The results were represented as a mean \pm standard error of the mean. The significant difference between the mean was compared by least significant difference, and the value was considered $\mathrm{p}<0.05$.

\section{RESULTS AND DISCUSSION}

\section{Characterization of AA nanoemulsion}

The effectiveness of the core material used to prepare AA nanoemulsion was determined from the total amount of AAs in nanoemulsions and AAs that were extracted from surface of nano particles. The core material of Lipoid S 75 had greater efficiency and a smaller particle size $(62.81 \pm 1.37 \mathrm{~nm})$ when compared to other core materials of Lipoid S 75-3 (171.60 \pm 4.54

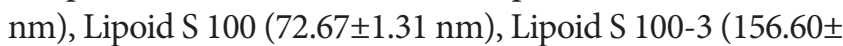
$3.51 \mathrm{~nm})$, Lecinol S $10(162.36 \pm 5.45 \mathrm{~nm})$, and HSPC 50 (158.57 $\pm 4.54 \mathrm{~nm}$ ) (Figure 1). Based on these properties, we selected Lipoid S 75 for the preparation of nanoemulsified AAs. Methionine with Lipoid S 75 was entrapped in unsaturated soybean lecithin with an encapsulation efficiency of $77.6 \%$. Similarly, cysteine with Lipoid S 75 was entrapped in unsaturated soybean lecithin with an encapsulation efficiency of $89.8 \%$. The average particle size distribution of nanoemulsion of methionine in Lipoid S 75 was in the range of $475.7 \mathrm{~nm}$, whereas, the particle size distribution of the cysteine in Lipoid S 75 was in the range of 431 to $475 \mathrm{~nm}$ by intensity as presented in Figure 2. The results of the current study showed that high-

Table 1. Oligonucleotide primer sets for quantitative real-time polymerase chain reaction

\begin{tabular}{llll}
\hline Gene & Forward primer $\left(\mathbf{5}^{\prime} \mathbf{-} \mathbf{3}^{\prime}\right)$ & Reverse primer $\left(\mathbf{3}^{\prime} \mathbf{-} \mathbf{5}^{\prime}\right)$ & Source \\
\hline$\alpha_{\mathrm{s} 2}$ casein & AGCTCTCCACCAGTGAGGAA & GCAAGGCGAATTTCTGGTAA & NM_174528.2 \\
$\beta$ casein & GTGAGGACAGCAGCAGCAAACA & TTTTGTGGGAGGCTGTTAGG & NM_181008 \\
$\kappa$ casein & CCAGGAGCAAACCAAGAC & TGCAACTGGTTTCTGTTGGT & NM_174294 \\
GAPDH & GGGTCATCATCTCTGCACCT & GGTCATAAGTCCCTCCACGA & XM_001252479 \\
\hline
\end{tabular}

GAPDH, glyceraldehyde 3-phosphate dehydrogenase. 


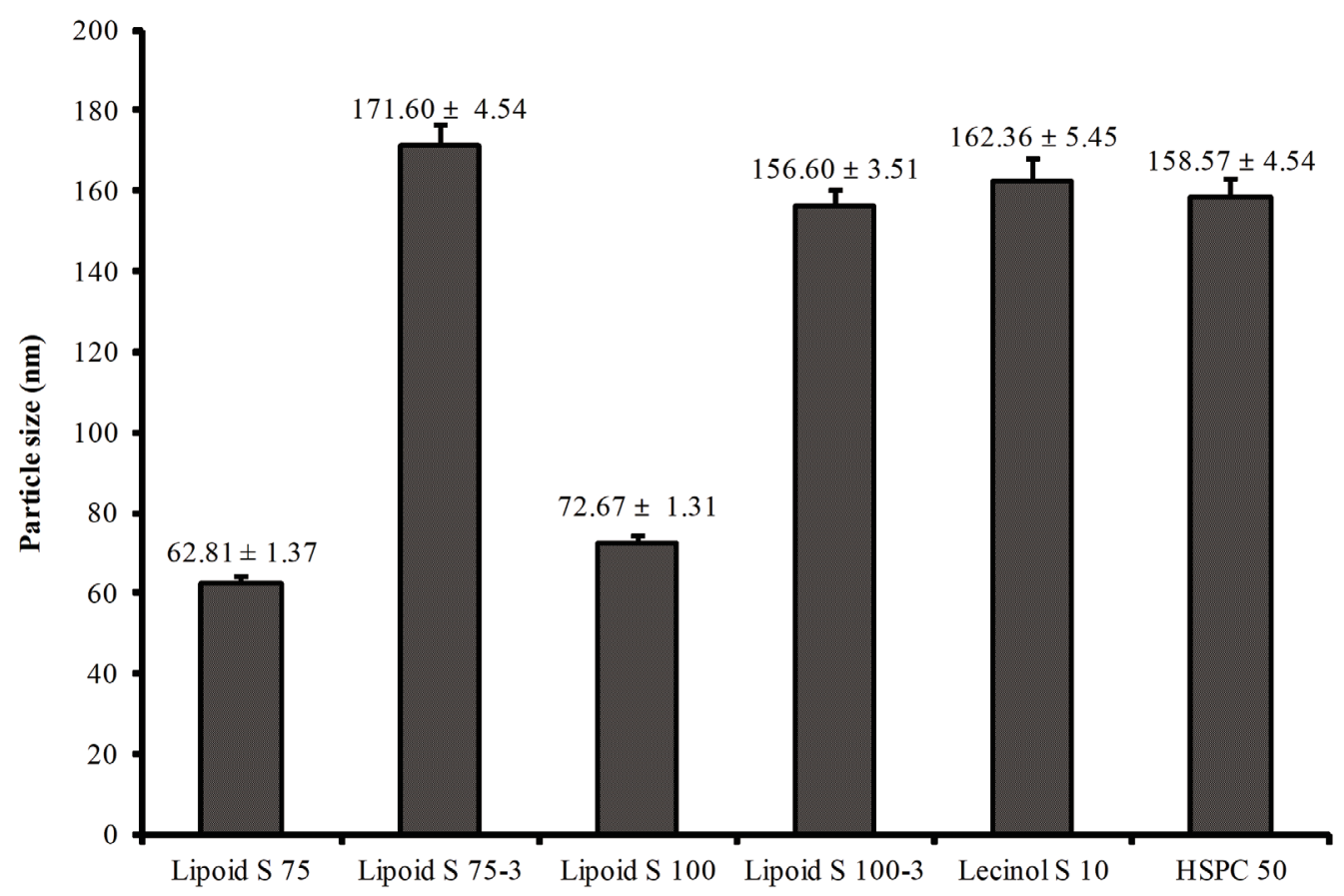

Figure 1. Particle size of core materials analyzed by dynamic light scattering correlation spectroscopy. The core material of Lipoid S 75 had greater efficiency and a smaller particle size when compared to other core materials of Lipoid S 75-3, S 100, S 100-3, Lecinol S 10, and HSPC 50. HSPC, hydrogenated soybean phosphatidylcholine.

pressure homogenization 3 times at 1,000 psi was the optimal condition to prepare an AA nanoemulsion. The zeta poten- tial of nanoemulsion of methionine and cysteine in Lipoid $\mathrm{S}$ 75 was $-11.8 \pm 4.42 \mathrm{mV}$ and $-14.6 \pm 1.63 \mathrm{mV}$, respectively (Fig-

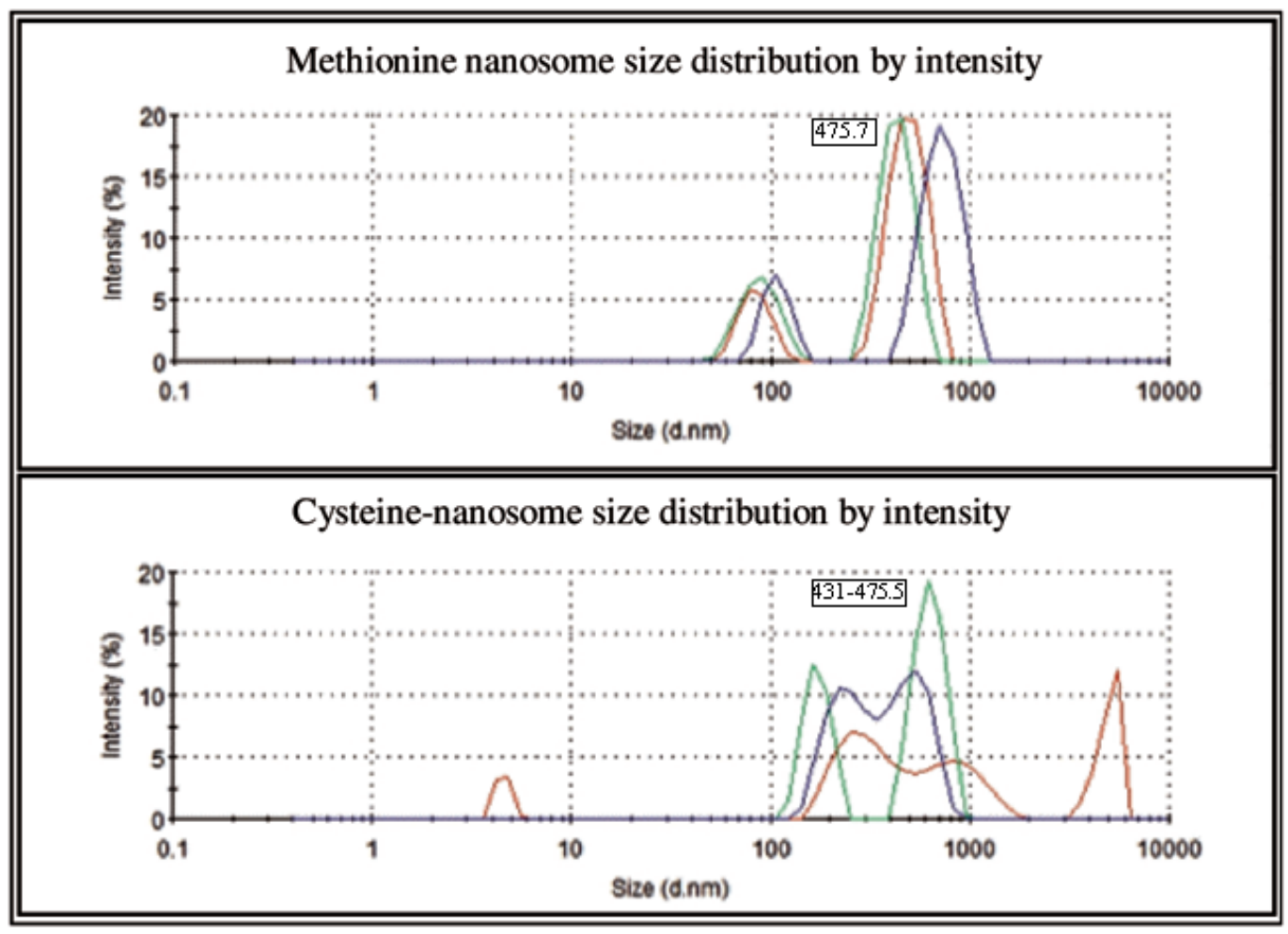

Figure 2. Particle size distribution of nanoemulsified methionine and cysteine nanosomes by intensity using dynamic light scattering correlation spectroscopy. The average particle size distribution of nanoemulsion of methionine in Lipoid S 75 was in the range of $475.7 \mathrm{~d} . \mathrm{nm}$, whereas, the particle size distribution of the cysteine in Lipoid S 75 in the range of 431 to $475 \mathrm{~d}$.nm by intensity. 


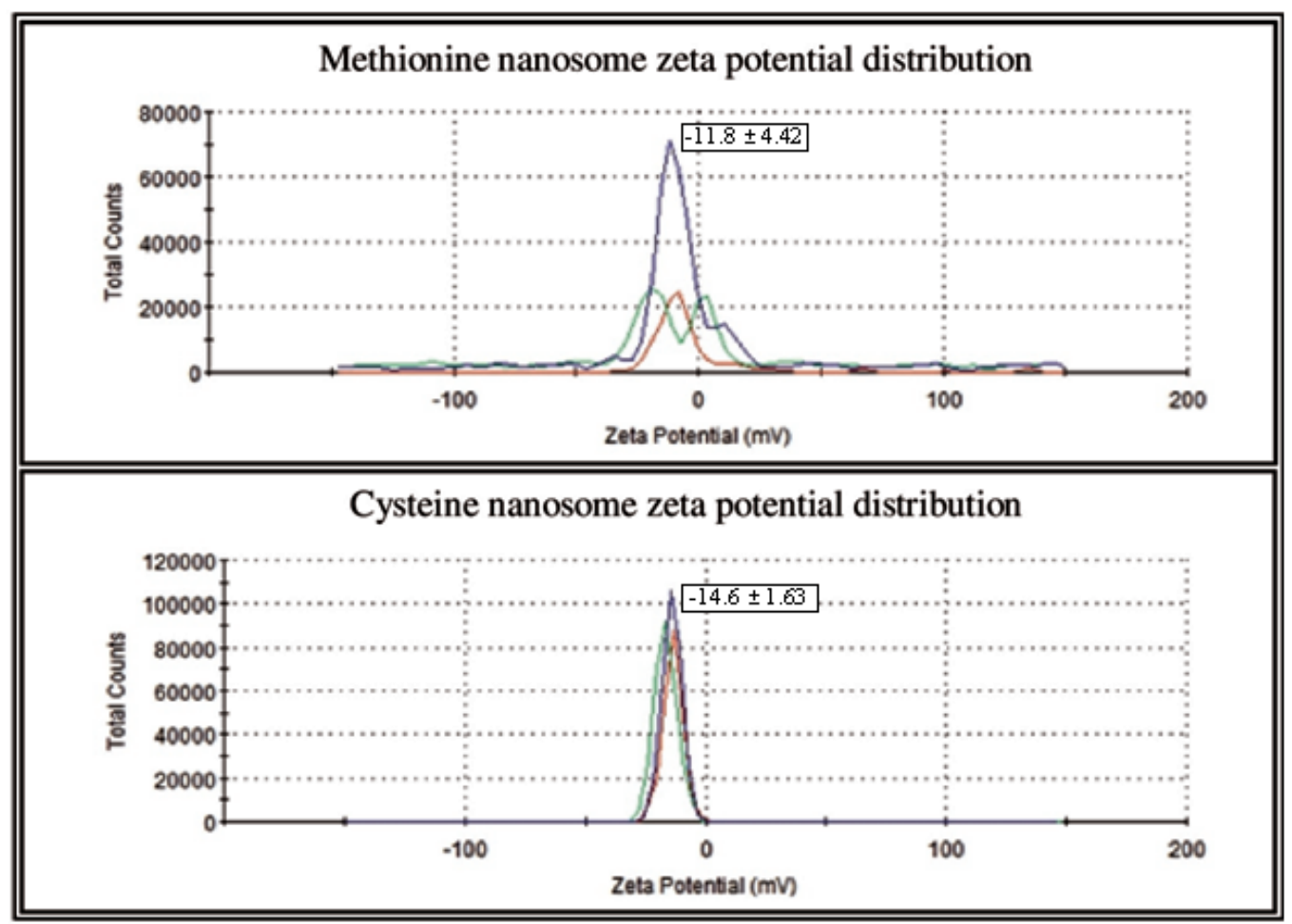

Figure 3. Zeta potential distribution of nanoemulsified methionine and cysteine nanosomes by intensity using dynamic light scattering correlation spectroscopy. The zeta potential of nanoemulsion of methionine and cysteine in Lipoid S 75 was $-11.8 \pm 3494.42 \mathrm{mV}$ and $-14.6 \pm 1.63 \mathrm{mV}$, respectively.

ure 3). The high PDI was caused by the main limitation of dynamic light scattering due to high concentration in the cuvette. This can lead to Brownian motion, such as multiple scattering with a decreased path length of particles. These phenomena can result in unfavorable particle size. Dynamic light scattering measures the hydrodynamic radius of a particle. A possible reason may be that Lipoid S 75 can attract water as more water is added; therefore, the dynamic diameter increases slightly. As the sample becomes more diluted, more Lipoid S 75 may move out of the particle, causing the particle size to decrease. Fortunately, this was not the case, as this can give substantial problems when this would be used for therapeutic applications [18]. In addition, all further studies of cytotoxicity and efficacy using methionine and cysteine in Lipoid S 75 on milk protein in MAC-T cells were performed based on the efficiency and particle size of nanoemulsion-based delivery systems.

\section{Cytotoxicity of nanosomes}

Colorimetric MTT assays were performed $24 \mathrm{~h}$ after treatment with or without nanoemulsified of AAs to highlight a possible cytotoxic effect of these emulsions (Table 2). Results of the present study showed that cell viability was slightly agitated at AA concentrations up to $500 \mu \mathrm{g} / \mathrm{mL}$ compared with control cells $(\mathrm{p}<0.05)$. Findings of the current study support those of Basirico et al [19], who previously reported that no fatty acid treatment on mammary epithelial cells reduced cell viability. However, at the same time, nanoemulsified AAs significantly increased the cell viability at concentrations up to $500 \mu \mathrm{g} / \mathrm{mL}$ when compared with non-emulsified AAs $(\mathrm{p}<0.05)$. Although the AAs had no significant effect regardless of the dose used, the dose-response curve showed that the administration of 100 to $500 \mu \mathrm{g} / \mathrm{mL}$ of nanoemulsified AAs increased the cell viability from $10.1 \%$ to $11.9 \%$, respectively when compared with free AAs.

Table 2. Efficacy of methionine, methionine-nanosome, cysteine, and cysteine-nanosome in bovine mammary epithelial cell viability

\begin{tabular}{lccrr}
\hline Items & Methionine & Methionine-nanosome & Cysteine & Cysteine-nanosome \\
\hline Control & $100 \pm 0.15$ & $100 \pm 0.16$ & $100 \pm 0.15$ & $100 \pm 0.12$ \\
$100 \mu \mathrm{g} / \mathrm{mL}$ & $89.21 \pm 0.77$ & $94.38 \pm 1.35$ & $93.16 \pm 0.84$ & $100.06 \pm 0.98$ \\
$200 \mu \mathrm{g} / \mathrm{mL}$ & $88.17 \pm 0.39$ & $91.78 \pm 2.92$ & $90.42 \pm 1.49$ & $98.42 \pm 1.51$ \\
$300 \mu \mathrm{g} / \mathrm{mL}$ & $85.37 \pm 2.46$ & $91.30 \pm 2.32$ & $89.89 \pm 2.35$ & $93.93 \pm 1.10$ \\
$400 \mu \mathrm{g} / \mathrm{mL}$ & $81.64 \pm 1.35$ & $88.89 \pm 4.27$ & $89.39 \pm 3.59$ & $93.34 \pm 0.76$ \\
$500 \mu \mathrm{g} / \mathrm{mL}$ & $80.46 \pm 3.37$ & $88.71 \pm 3.52$ & $89.21 \pm 2.96$ & $90.81 \pm 1.19$ \\
\hline
\end{tabular}


Effects of methionine and cysteine nanoemulsion on the expression of caseins

Several studies have evaluated the contribution of AAs to mammary gland metabolism and protein secretion and synthesis [20]. In this experiment, the potential effect of nanoemulsified methionine and cysteine on milk protein casein expression in bovine epithelial mammary cells was studied. The current study showed that, compared with the non-emulsified methionine group, the supplementation of methionine to Lipoid S 75 generated significantly increased effects on the casein expression. Figure 4 shows that nanoemulsified methionine had stimulatory effects of 2 -fold on the $\alpha_{\mathrm{s} 2}$-casein, 5 -fold on the $\beta$-casein, and 2-fold on the $\kappa$-casein expression when compared with the non-emulsified methionine group, which sustained the notion that methionine is a key limiting factor for milk protein synthesis. Our study results confirmed that nanoemulsified methionine promoted milk protein $\alpha$-casein, $\beta$-casein, and $\mathrm{k}$-casein expression in cultured mammary epithelial cells as compared with non-emulsified methionine. Our current study findings agreed with those reported previously that histidine-containing dipeptide promoted milk protein production compared with supplementation of free histidine [21]. However, the mechanism of nanoemulsified AA utilization is complicated and unclear. It has been previously demonstrated that peptides containing methionine can easily utilize free methionine supplementation for mammary tissue and milk protein synthesis in cultured mammary epithelial cells [22]. A rat model experiment clearly showed that dipeptides were hydrolyzed extracellularly when compared with free AAs [23]. However, it remains unclear why supplementation with dipeptides containing methionine to cultured mammary epithelial cells significantly increased efficiency of $\alpha_{\mathrm{s} 2}$-casein gene expression, but $\alpha_{\mathrm{s} 1}$-casein gene expression was not increased when supplementation of free methionine was higher than $60 \mu \mathrm{g} / \mathrm{mL}$ in cultured bovine mammary epithelial cells [24]. The free methionine transporter may be saturated at $60 \mu \mathrm{g} / \mathrm{mL}$, but dipeptides containing methionine may be absorbed through different transporters located on bovine mammary epithelial cell membranes [25]. This transporter may be from a different species, so bovine mammary epithelial cell membranes containing the transporter have a high affinity and absorb dipeptide methionine directly for milk protein casein synthesis. Figure 5 shows the effect of nanoemulsified cysteine supplementation on casein expression. Compared with non-emulsified cysteine, the expression of $\alpha_{\mathrm{s} 2}$-casein, $\beta$-casein, and $\kappa$-casein was decreased by emulsified cysteine. The cysteine content is lower in cow's milk than in human milk because methionine content is higher in cow's milk. Therefore, the methionine/cysteine ratio is 2- to 3 -fold greater in cow's milk than that of other mammals, but 7 -fold greater
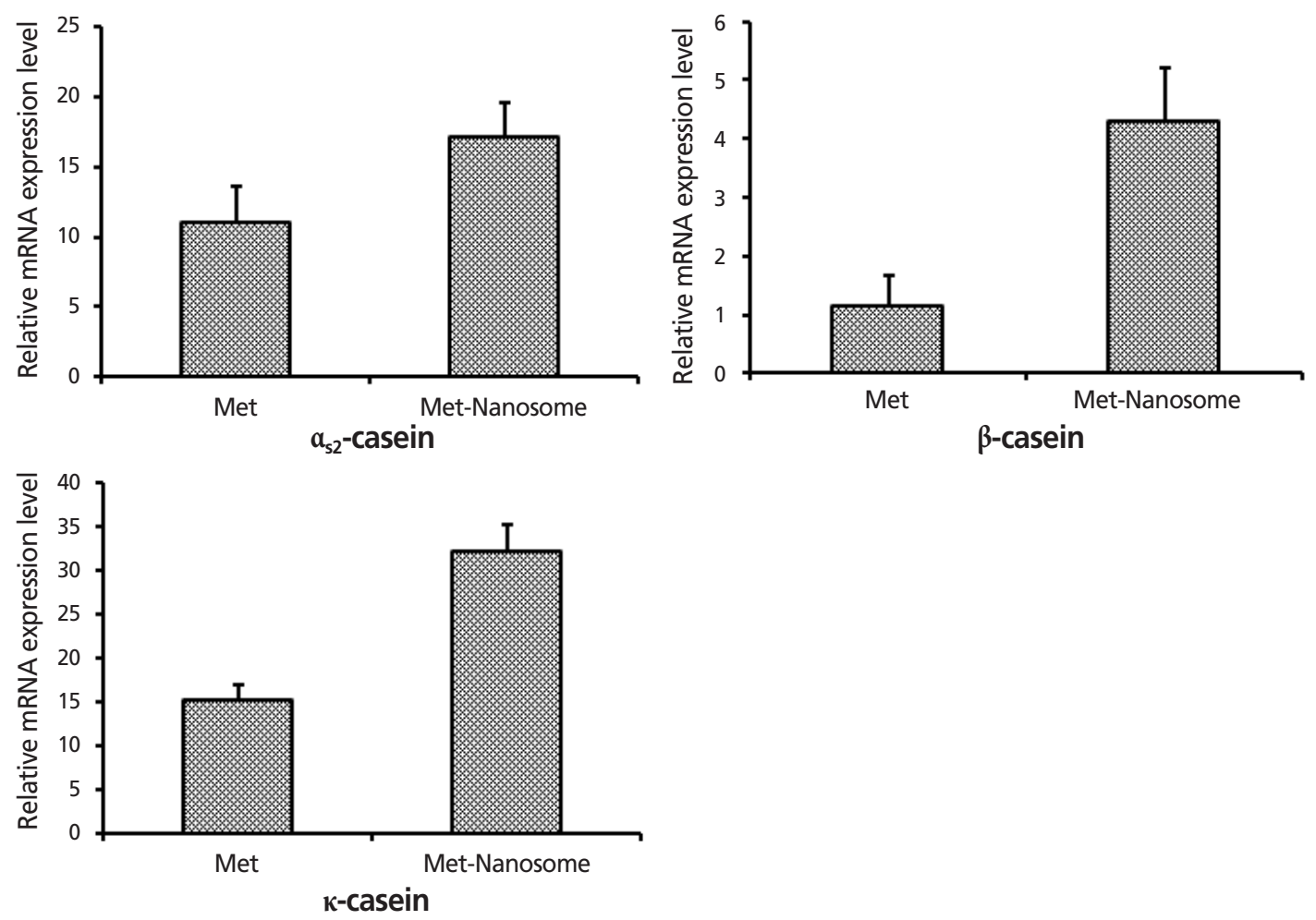

Figure 4. Effect of free-methionine and nanoemulsified methionine on casein gene expression in bovine mammary epithelial cells analyzed by quantitative reverse transcription polymerase chain reaction. The nanoemulsified methionine had stimulatory effects of 2 fold on the $\alpha_{52}$-casein, 5 fold on the $\beta$-casein, and 2 fold on the $\kappa$-casein expression when compared with the non-emulsified methionine group. 

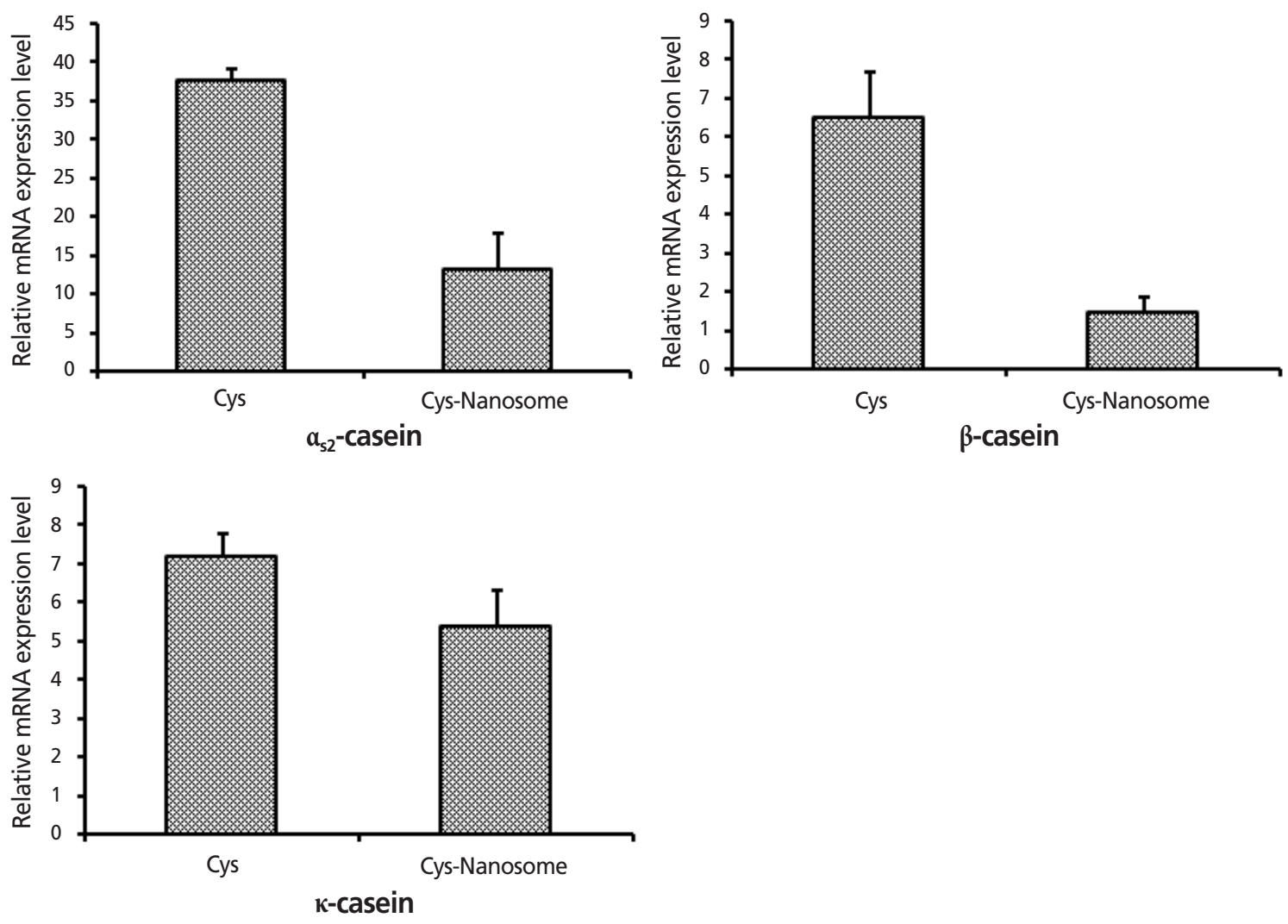

Figure 5. Effect of free-cysteine and nanoemulsified cysteine on casein gene expression in bovine mammary epithelial cells analyzed by quantitative reverse transcription polymerase chain reaction. Compared with non-emulsified cysteine, the expression of $\alpha_{52}$-casein, $\beta$-casein, and $\kappa$-casein was decreased by emulsified cysteine.

in human milk. Two considerable characteristics of AA composition of human milk are the ratio between the sulfurcontaining AAs methionine and cysteine, and the low level of aromatic AAs phenylalanine and tyrosine because of the low levels of the specific enzymes required to metabolize them. Wu et al [26] demonstrated that AAs, including arginine, cysteine, glutamine, and leucine act as both cell signaling candidates and regulators for gene expression and protein phosphorylation pathways. The expression of the $\alpha_{\mathrm{s} 2}$-casein, $\beta$-casein, and $\kappa$-casein genes was decreased when nanoemulsified cysteine was used to supplement the bovine mammary epithelial cells. Our study results agree with those of Raggio et al [27], who reported that the efficiency of the absorbed AAs into milk protein decrease markedly as protein delivery increases. However, further studies are needed to clarify the nature of the response by mammary cells to increase AA supply.

\section{CONCLUSION}

In conclusion, the medium (soybean lecithin) used for mixing AAs (methionine and or cysteine) for emulsification enhanced encapsulation capability, size, and PDI. Addition of core material Lipoid S 75-based nanoemulsion of methionine to bovine mammary epithelial cells showed the potential to influence milk protein $\alpha_{\mathrm{s} 2}$-casein, $\beta$-casein, and $\kappa$-casein when compared with free methionine and cysteine. Therefore, further study is needed to determine how a nanoemulsion-based model may help to clarify the regulation mechanism of methionine and cysteine on casein expression through the mTOR pathway in bovine mammary epithelial cells.

\section{CONFLICT OF INTEREST}

We certify that there is no conflict of interest with any financial organization regarding the material discussed in the manuscript.

\section{ACKNOWLEDGMENTS}

The authors are grateful to the Cooperative Research Program for Agricultural Science and Technology Development (Project title: Biological modulation for optimal production of dairy cows during the transition period; Project No: PJ008993012013) of the Rural Development Administration of the Republic of Korea. This study was supported by the National Institute of Animal Science's Postdoctoral Fellowship Program of the Rural Development Administration of the Republic of Korea. 


\section{REFERENCES}

1. Arriola Apelo SI, Knapp JR, Hanigan MD. Current representation and future trends of predicting amino acid utilization in the lactating dairy cow. J Dairy Sci 2014;97:4000-17.

2. Bionaz M, Hurley W, Loor J. Milk protein synthesis in the lactating mammary gland: insights from transcriptomics analyses. In: Hurley W, Editor. Milk protein. Chapter 11. London, UK: InTech; 2012. pp. 285-324.

3. Hristov AN, Price WJ, Shafii B. A meta-analysis examining the relationship among dietary factors, dry matter intake, and milk and milk protein yield in dairy cows. J Dairy Sci 2004;87: 2184-96.

4. Kim DH, Sarbassov DD, Ali SM. mTOR interacts with raptor to form a nutrient-sensitive complex that signals to the cell growth machinery. Cell 2002;110:163-75.

5. Wang C, Liu HY, Wang YM. Effects of dietary supplementation of methionine and lysine on milk production and nitrogen utilization in dairy cows. J Dairy Sci 2010;93:3661-70.

6. Appuhamy JA, Knoebel NA, Nayananjalie WA. Isoleucine and leucine independently regulate mTOR signaling and protein synthesis in MAC-T cells and bovine mammary tissue slices. J Nutr 2012;142:484-91.

7. Hanigan MD, Crompton LA, Bequette BJ, Mills JA, France J. Modelling mammary metabolism in the dairy cow to predict milk constituent yield, with emphasis on amino acid metabolism and milk protein production: model evaluation. J Theor Biol 2002;217:311-30.

8. Kimball SR. Regulation of global and specific mRNA translation by amino acids. J Nutr 2002;132:883-6.

9. Moshel Y, Rhoads RE, Barash I. Role of amino acids in translational mechanisms governing milk protein synthesis in murine and ruminant mammary epithelial cells. J Cell Biochem 2006; 98:685-700.

10. Yang Q, Inoki K, Kim E. TSC1/TSC2 and Rheb have different effects on TORC1 and TORC2 activity. Proc Nat Acad Sci USA 2006;103:6811-6.

11. Bequette BJ, Hanigan MD, Calder AG. Amino acid exchange by the mammary gland of lactating goats when histidine limits milk production. J Dairy Sci 2000;83:765-75.

12.Prizant RL, Barash I. Negative effects of the amino acids Lys, His, and Thr on S6K1 phosphorylation in mammary epithelial cells. J Cell Biochem 2008;105:1038-47.

13. Burgos SA, Dai M, Cant JP. Nutrient availability and lactogenic hormones regulate mammary protein synthesis through the mammalian target of rapamycin signaling pathway. J Dairy Sci 2010;93:153-61.

14.Lopez A, Gavara R, Lagaron J. Bioactive packaging: turning foods into healthier foods through biomaterials. Trends Food Sci Technol 2006;17:567-75.

15. Schubert MA, Muller-Goymann CC. Characterization of surfacemodified solid lipid nanoparticles (SLN): Influence of lecithin and nonionic emulsifier. Eur J Pharm Biopharm 2005;61:7786.

16.Erjavec V, Pavlica Z, Sentjurc M, Petelin M. In vivo study of liposomes as drug carriers to oral mucosa using EPR oximetry. Int J Pharm 2006;307:1-8.

17. Kidd P, Head K. A review of the bioavailability and clinical efficacy of milk thistle phytosome: a silybin-phosphatidylcholine complex (siliphos). Altern Med Rev 2005;10:193-203.

18. Justin V. Physicochemical characterization of a nanodispersion, obtained with a phase inversion temperature technique [Thesis]. Halle, Saxony-Anhalt, Germany: Martin Luther University of Halle-Wittenberg; 2015.

19. Basirico L, Morera P, Dipasquale D, Troscher A, Bernabucci U. Comparison between conjugated linoleic acid and essential fatty acids in preventing oxidative stress in bovine mammary epithelial cells. J Dairy Sci 2017;100:2299-309.

20. Tagari H, Webb K, Theurer B, et al. Mammary uptake, portaldrained visceral flux, and hepatic metabolism of free and peptide-bound amino acids in cows fed steam-flaked or dryrolled sorghum grain diets. J Dairy Sci 2008:91:679-97.

21. Backwell FRC, Bequette BJ, Wilson D, et al. Evidence for the utilization of peptides for milk protein synthesis in the lactating dairy goat in-vivo. Am J Physiol 1996;271:R955-60.

22. Pan Y, Bender PK, Akers RM, Webb KE. Methionine-containing peptides can be used as methionine sources for protein accretion in cultured C2C12 and MAC-T cells. J Nutr 1996; 126:232-41.

23. Shennan DB, Calvert DT, Backwell FRC, Boyd CAR. Peptide aminonitrogen transport by the lactating rat mammary gland. Biochim Biophys Acta Biomem 1998;1373:252-60.

24. Yang JY, Wu YM, Liu JX. Effects of methionine and methionylmethionine on expression of casein as1 gene in cultured bovine mammary epithelial cells. J Agric Biotechnol 2007;15:24-7.

25. Groneberg DA, Döring F, Theis S, et al. Peptide transport in the mammary gland: expression and distribution of PEPT2 mRNA and protein. Am J Physiol Endocrinol Metab 2002;282: E1172-9.

26. Wu G, Bazer FW, Davis TA, et al. Arginine metabolism and nutrition in growth, health and disease. Amino Acids 2009; 37:153-68.

27. Raggio G, Pacheco D, Berthiaume R, et al. Effect of level of metabolizable protein on splanchnic flux of amino acids in lactating dairy cows. J Dairy Sci 2004;87:3461-72. 